\title{
Morphometric Study of Scapular Index in South Indian Population: An Observational Study
}

\section{ABSTRACT}

Introduction: Scapula is a flat, triangular bone forming very important shoulder joint and with the evolution it has undergone modifications especially in its shape. It can be best studied with the help of Scapular Index (SI)-which denotes the relationship of breadth of the scapula to the length of the scapular bone.

Aim: To determine the morphometric dimensions and SI in South Indian population and to compare it with various ethnic groups and laterality.

Materials and Methods: The present retrospective observational study utilised a total of 98 scapulae of both right and left sides from South Indian population available over a period of one year in the Department of Anatomy of tertiary care centre. The relationship of Scapular Length (SL) with its breadth was expressed as the SI. The obtained values are analysed using Statistical Package for Social Sciences (SPSS) Software version 21.0. Mean, ratio, percentage and standard deviations were applied and results were analysed.

Results: The breadth of the scapula ranged from $83-112 \mathrm{~mm}$ and the mean value was $96.71 \pm 6.98 \mathrm{~mm}$. The length of scapula ranges from $104.5-165 \mathrm{~mm}$ and the mean value was $136 \pm 13.52 \mathrm{~mm}$. The SI was ranging from $55.62-87.08$ and the mean value was $71.46 \pm 5.64$. The Infraspinous Index (IB), ranged from 68.42121.33 and the mean value was $94.14 \pm 10.98$.

Conclusion: The morphometric data of the present study can be not only in comparative anatomy between the different races, but also between the subpopulations of our country also. The data of the present study can be useful for manufacturing various prosthetic products, for procedures such as prosthetic positioning of scapula and also in various surgical maneuvers such as screw fixations, replacements of the shoulder joint in our subset of population for various medical fields such as Orthopaedics.

\section{INTRODUCTION}

Scapula is a flat, triangular bone of the pectoral girdle, situated on the posterior side of the rib cage, extending from T2 to T7. Scapula has a body with subscapular fossa on its costal aspect and supraspinous and infraspinous fossa on its dorsal aspect. The triangular spine, the acromion process and the coracoid process also lies in its dorsal aspect. It consists of three angles, superior, inferior and lateral; the lateral angle is truncated and bears the glenoid cavity [1].

With evolution two parts of human scapula, the dorsal component representing scapula proper and the ventral component representing coracoids are fused together [2]. Various studies on the development of scapula agreed to that, the peculiar shape of scapula is a mammalian characteristic as against the forces applied by the surrounding muscles [3].

With the evolution, scapula has undergone modifications especially in its shape. These modifications can be best studied with the help of SI-which denotes the relationship of breadth of the scapula to the length of the scapular bone. In previous studies, it is noted that, in quadrupeds the scapula is long and narrow and the $\mathrm{SI}$ is very high and it progressively falls as we approach the mammals, which walks with body upright position such as humans, where the forelimb is completely free [4]

The measurements of scapula can give a lot of valuable information to Orthopaedic surgeons in cases like chronic shoulder dislocation and surgeries like shoulder arthroplasty. It also is of utmost importance in solving many medicolegal cases for forensic experts and also for comparative anatomy purposes like anthropologists [5]. Since the available information in the literature was less, we made a sincere effort for scapular measurements in south Indian population [6,7]. Authors tried to compare the morphometry of scapula with various other populations not only in our subcontinent, but also with distant ethnic origins. The aim of the present study was to compare the scapular indices between right and left sides in our population and also among various ethnic origins which were not done in the previous studies.

\section{MATERIALS AND METHODS}

The present retrospective observational study was performed for a period of one year between January 2019 to December 2019. The study was conducted on dry human scapulae available at Department of Anatomy, Father Muller Medical College Mangalore, Karnataka, India after the approval of Institutional Ethics Committee (FMMCIEC/CCM/56/2019).

Inclusion criteria: Adult intact human dry scapulae of undetermined sex of both sides which were of good quality without any damages were included in the study.

Exclusion criteria: Scapulae which were deformed and damaged were excluded. Also, scapulae of infants and children were exempted from the study.

\section{Study Procedure}

A total of 98 scapulae of both right and left sides were taken out of which 47 were of right sided and 51 were left sided. The scapulae were fixed to the osteometric board and measurements were taken in $\mathrm{mm}$ with the help of the Vernier Caliper. Each measurement was recorded twice to minimise the observational error. Based on the findings of Nazir $\mathrm{M}$ et al., the scapular measurements were estimated using the following points [Table/Fig-1] [8].

The Scapular measurements taken were as follows:

Scapular Breadth (SB): Measurement between the points $E$ and F [Table/Fig-2a].

Scapular Length (SL): Measurement between the points $\mathrm{G}$ and $\mathrm{H}$ [Table/Fig-2b]. 

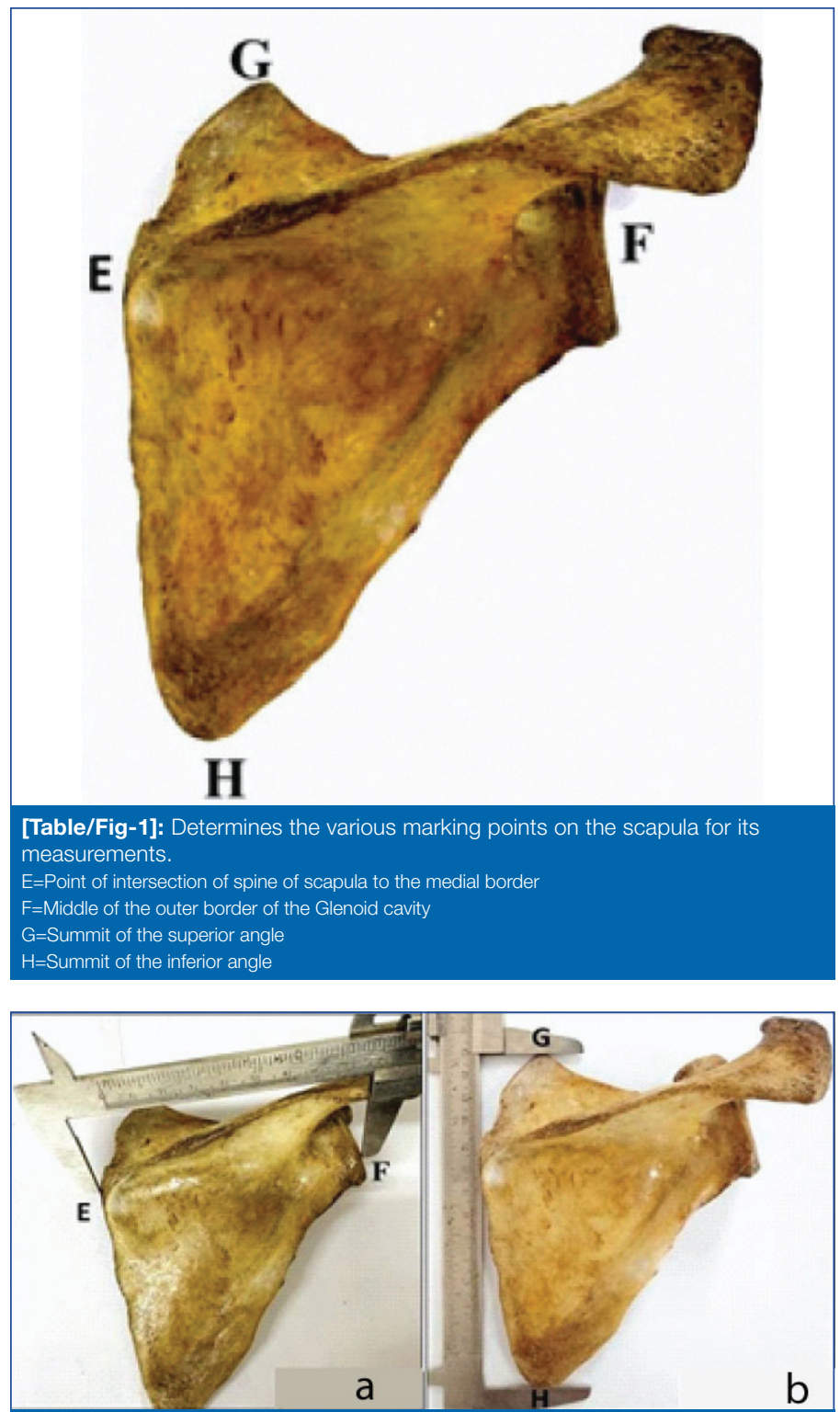

[Table/Fig-2]: Measuring Scapular Breadth (SB) and Scapular Length (SL) using Vernier caliper in right scapula in the present study.

Infraspinous Length (IL): Measurement between the points $\mathrm{E}$ and $\mathrm{H}$.

The Scapular Index (SI) and Infraspinous Index (IB) by using the formulae [5]:

$\mathrm{SI}=(100 \times \mathrm{SB}) / \mathrm{SL}$

Also, $\mathrm{IB}=(100 \times \mathrm{SB}) / \mathrm{IL}$

\section{STATISTICAL ANALYSIS}

The observational findings were tabulated in Excel sheet and analysed. The results were tabulated and expressed in terms of mean, ratios, percentage and standard deviation was derived using SPSS software version 21.0. Scapular indices were also analysed between right and left sides. A comparison was made between the obtained means of both sides using the student's t-test and p-value less than 0.05 was considered statistically significant.

\section{RESULTS}

In the present study, breadth of the scapula ranged from 83-112 mm and the mean value is $96.71 \mathrm{~mm}$ and 6.98 as standard deviation, respectively. The maximum number of scapula $(24.49 \%)$ is in the range of $101-105 \mathrm{~mm}$, followed by $23.47 \%$ in the range of 91 $95 \mathrm{~mm}$ and only $2.04 \%$ of the scapula was in the range of $111-115$ [Table/Fig-3].

The length of the scapula ranges from 104.5-165 mm and the mean value is $136 \mathrm{~mm}$ and $13.52 \mathrm{~mm}$ as standard deviation. The maximum of scapula (31.63 \%) was in the range of $131-140 \mathrm{~mm}$, followed by $25.51 \%$ in the range of $141-150 \mathrm{~mm}$ and only $5.11 \%$ of the scapula was in the range of 100-110 [Table/Fig-4].

\begin{tabular}{|l|c|c|}
\hline Scapular breadth $(\mathrm{mm})$ & No. of scapula & Percentage (\%) \\
\hline $80-85$ & 4 & 4.08 \\
\hline $86-90$ & 17 & 17.35 \\
\hline $91-95$ & 23 & 23.47 \\
\hline $96-100$ & 18 & 18.37 \\
\hline $101-105$ & 24 & 24.49 \\
\hline $106-110$ & 10 & 10.20 \\
\hline 111-115 & 2 & 2.04 \\
\hline \\
[Table/Fig-3]: Distribution of scapula according to its breadth in the present \\
\hline
\end{tabular}
study $(\mathrm{N}=98)$.

\begin{tabular}{|l|c|c|}
\hline Scapular length $(\mathrm{mm})$ & No. of scapula & Percentage (\%) \\
\hline $100-110$ & 5 & 5.11 \\
\hline $111-120$ & 6 & 6.12 \\
\hline $121-130$ & 19 & 19.39 \\
\hline $131-140$ & 31 & 31.63 \\
\hline $141-150$ & 25 & 25.51 \\
\hline $151-160$ & 6 & 6.12 \\
\hline $161-170$ & 6 & 6.12 \\
\hline
\end{tabular}

[Table/Fig-4]: Distribution of scapula according to its Length in the present study $(\mathrm{N}=98)$.

The relationship of SL with its breadth is expressed as $\mathrm{SI}$ and it ranges from $55.62-87.08$ and the mean value is 71.46 with 5.64 as standard deviation respectively. The maximum scapula $(43.88 \%)$ is in the range of $71-75$ followed by $27.56 \%$ in the range of $66-70$ and only $1.02 \%$ of the scapula is in the range of $86-90$ [Table/Fig-5].

\begin{tabular}{|l|c|c|}
\hline Scapular index & No. of scapula & Percentage (\%) \\
\hline $55-60$ & 2 & 2.04 \\
\hline $61-65$ & 12 & 12.24 \\
\hline $66-70$ & 27 & 27.56 \\
\hline $71-75$ & 43 & 43.88 \\
\hline $76-80$ & 7 & 7.14 \\
\hline $81-85$ & 6 & 6.12 \\
\hline $86-90$ & 1 & 1.02 \\
\hline [Table/Fig-5]: Distribution of scapula according to scapular index in our study \\
(N=98).
\end{tabular}

Regarding the IB, it ranges from 68.42-121.33 and the mean value is 94.14 and 10.98 as standard deviation respectively. The maximum number of scapula (33.67\%) is in the range of $96-105$ followed by $31.64 \%$ in the range of $86-95$. Only $2.04 \%$ of the scapula is in the range of 116-125 [Table/Fig-6].

\begin{tabular}{|l|c|c|}
\hline Infraspinous index (IB) & No. of scapula & Percentage (\%) \\
\hline $65-75$ & 8 & 8.16 \\
\hline $76-85$ & 15 & 15.31 \\
\hline $86-95$ & 31 & 31.64 \\
\hline $96-105$ & 33 & 33.67 \\
\hline $106-115$ & 9 & 9.18 \\
\hline $116-125$ & 2 & 2.04 \\
\hline $\begin{array}{l}\text { [Table/Fig-6]: Distribution of scapula according to its Infraspinous Index (IB) in our } \\
\text { study (N=98). }\end{array}$
\end{tabular}

The SB and length (in $\mathrm{mm}$ ) were slightly increased in left scapulae as compared to the right-side, whereas scapular indices such as SI and IB were marginally increased on the right-side. However, there was no statistical significant difference for these parameters [Table/Fig-7]. 


\begin{tabular}{|l|c|c|c|}
\hline Scapular parameters & $\begin{array}{c}\text { Left scapulae } \\
\text { (Mean } \pm \text { SD) }(\mathrm{N}=51)\end{array}$ & $\begin{array}{c}\text { Right scapulae } \\
(\text { Mean } \pm S D)(N=47)\end{array}$ & $\begin{array}{c}p- \\
\text { value }\end{array}$ \\
\hline Scapular breadth $(\mathrm{mm})$ & $96.79 \pm 6.33$ & $96.39 \pm 7.56$ & 0.77 \\
\hline Scapular length $(\mathrm{mm})$ & $136.46 \pm 13.09$ & $135.64 \pm 14.28$ & 0.71 \\
\hline Scapular index & $71.26 \pm 4.93$ & $71.54 \pm 6.52$ & 0.816 \\
\hline Infraspinous index & $92.37 \pm 11.63$ & $96.32 \pm 9.81$ & 0.08 \\
\hline
\end{tabular}

\section{DISCUSSION}

The present study deals with the scapular indices like its breadth, length, IL, SI and IB in south Indian population in Karnataka region. Similar studies have been carried out by a number of workers in other races and other groups of population and sincere effort were made to compare the findings with the studies done in the past.

Scapular Breadth (SB): In the present study, the SB was ranging from 83-112 mm, while in other ethnic studies it was ranging between 83-126 mm. The mean SB in various past studies in other ethnic populations ranges between 92-104 mm [4,9-11]. Mean SB of $96.71 \pm 6.98 \mathrm{~mm}$ in the present study was very much comparable to the study done by Singal $\mathrm{G}$ et al., in Saurashtra region among Gujarat population, where the values were $96.4 \mathrm{~mm}$ [5]. However, mean SB were $10.2 \pm 0.81 \mathrm{~cm}$ in Tamil Nadu population, $105.59 \pm 50.8 \mathrm{~mm}$ in Andhra population and $98.16 \mathrm{~mm}$ in Kashmiri populations $[7,8]$.

So, the mean SB in South Indian population is very nearer to that of Saurashtra region of Gujarat population [5].

Scapular Length (SL): The SL in present study was ranging from 104.5-165 mm and mean SL was 136.08 $\pm 13.52 \mathrm{~mm}$ which was lower than past studies in other ethnic populations, where it was ranging from 155-157 mm [4,9-11]. However, mean scapula length was 141.7 in Gujarat, $12.5 \pm 1.01 \mathrm{~cm}$ in Tamil Nadu and $143.27 \pm 11.14$ in Andhra populations [5-7]. The present values were comparable with that of Kashmiri population, in which the mean SL was $137 \pm 20.09 \mathrm{~mm}[8]$.

Scapular Index (SI): These values in the present study was ranging from 55.62-87.08 and the mean SI in the present study was $71.46 \pm 5.64$ and about $44 \%$ of them were in the range of $71-75$ [Table/Fig-5]. The mean values in the studies from other ethnic races varied from minimum of 57.3 in Peruvian population to a maximum of 71.7 in that of Negroes [Table/Fig-8] [4-6,8,9,12,13]. However, the values of mean $\mathrm{SI}$ in our subcontinent were $68.5 \pm 4 \mathrm{~mm}$ in Gujarat, $74.0 \pm 4.18$ in Tamil Nadu, $73.99 \pm 4.6 \mathrm{~mm}$ in Andhra and $72 \pm 11.41$ in Kashmiri populations [5-8]. So, the SI values of current study are very close to that of Kashmiri population of our ethnic race and also to that of Negroid Population in other ethnic races. Similar observations were made by Nithya $V$ et al., 2020 in Tamil Nadu populations which is comparable with the present study [Table/Fig-8] [6].

Infraspinous Index (IB): These values observed in the present study were ranging from $68.42-121.33$. About $33.67 \%$ were in the range of $96-105$ followed by $31.64 \%$ in the range of 86-95, [Table/Fig-6]. However, the mean IB observed in the present study is 94.14 with the standard deviation of 10.98. The mean value varies from 75.1$120 \mathrm{~mm}$ in many other different races [Table/Fig-9] [4,5,7-9,12,13]. However, the values of mean IB in ethnic race were 94.6 \pm 7.6 in Gujarati people, $98.33 \pm 5.86 \mathrm{~mm}$ in Andhra region and 92.83 \pm 15.86 in Kashmiri populations $[5,7,8]$. So, the IB in the present study are very close to that of Gujarat population in saurashtra region in our ethnic race and also to that of Negroid Population in distant ethnic races [Table/Fig-9] [5].

\begin{tabular}{|c|c|c|c|c|}
\hline $\begin{array}{l}\text { Year of } \\
\text { study }\end{array}$ & Author & $\begin{array}{l}\text { No. of scapula } \\
\text { observed }\end{array}$ & Race/Region & $\begin{array}{l}\text { Mean scapular } \\
\text { index }\end{array}$ \\
\hline \multirow{8}{*}{$1879[4]$} & \multirow{8}{*}{$\begin{array}{l}\text { Flower WH and } \\
\text { Garson JG }\end{array}$} & 200 & European & 65.2 \\
\hline & & 6 & Bushman & 66.7 \\
\hline & & 2 & Peruvian & 57.3 \\
\hline & & 6 & Negro & 71.7 \\
\hline & & 6 & Tasmanian & 60.3 \\
\hline & & 4 & Eskimos & 61.6 \\
\hline & & 12 & Australian & 68.9 \\
\hline & & 21 & Andaman & 69.8 \\
\hline 1944 [12] & Inman VT & --- & --- & 64 \\
\hline 2008 [13] & $\begin{array}{l}\text { Guise Sheridan } \\
\text { S et al., }\end{array}$ & --- & --- & 68.1 \\
\hline $2013[5]$ & Singhal G et al., & 162 & Saurashtra & 68.5 \\
\hline $2014[7]$ & $\begin{array}{l}\text { Krishnaiah M } \\
\text { et al., }\end{array}$ & 50 & Nalagonda & 73.99 \\
\hline 2018 [8] & Nazir M et al., & 60 & Kashmir & 72 \\
\hline $2020[6]$ & Nithya $\vee$ et al., & 150 & Tamil Nadu & 74 \\
\hline 2020 & Present Study & 98 & South Indian & 71.46 \\
\hline
\end{tabular}

with present study $[4-6,8,9,12,13]$.

\begin{tabular}{|c|c|c|c|c|}
\hline $\begin{array}{l}\text { Year of } \\
\text { study }\end{array}$ & Author & $\begin{array}{c}\text { No. of } \\
\text { scapula } \\
\text { observed }\end{array}$ & Race/Region & $\begin{array}{l}\text { Mean } \\
\text { infraspinous } \\
\text { index }\end{array}$ \\
\hline \multirow{8}{*}{$1879[4]$} & \multirow{8}{*}{$\begin{array}{l}\text { Flower WH and } \\
\text { Garson JG }\end{array}$} & 200 & European & 89.4 \\
\hline & & 6 & Bushman & 90.7 \\
\hline & & 2 & Peruvian & 75.1 \\
\hline & & 6 & Negro & 100.9 \\
\hline & & 6 & Tasmanian & 81.4 \\
\hline & & 4 & Eskimos & 80.5 \\
\hline & & 12 & Australian & 92.5 \\
\hline & & 21 & Andaman & 92.7 \\
\hline 1944 [12] & Inman VT et al., & --- & --- & 120.0 \\
\hline $2013[5]$ & Singhal $\mathrm{G}$ et al., & 162 & Saurashtra & 94.6 \\
\hline $2014[7]$ & Krishnaiah M et al., & 50 & Nalagonda & 98.33 \\
\hline 2018 [8] & Nazir M et al., & 60 & Kashmir & 92.83 \\
\hline 2020 & Present Study & 98 & South Indian & 94.14 \\
\hline
\end{tabular}

\section{Limitation(s)}

The current study was done on human dry scapulae to determine the various scapular indices. However, the sexual dimorphism of scapulae was not determined. Further in depth, detailed studies can be done to explore various human scapular measurements and indices with respect to age, sex and radiological findings. This may further help in determining the race just by using these indices which can be of importance to forensic experts and anthropologists.

\section{CONCLUSION(S)}

Various scapular measurements like length, breadth and IL and its indices like SI and IB varies in different races and different ethnic groups. The present study showed mean SI values close to Kashmir population in India and to Negroid race among ethnic groups. The mean IB values were close to Gujarat population in India and to Negroid race among other ethnic groups. Even though these indices were slightly increased on the right-side, there was no statistical significant difference between both the sides. These values are essential and can be used in comparative anatomy between the different races, but also between the sub-populations of our country also. These studies can be useful for manufacturing various prosthetic products, for procedures such as prosthetic positioning of scapula and 
also in various surgical maneuvers like screw fixations, replacements of the shoulder joint in our subset of populations.

\section{REFERENCES}

[1] Black S. External Skull. In: Susan Standring, editor. Gray's Anatomy: The Anatomical Basis of Clinical Practice, $41^{\text {st }}$ edn. Churchill-Livingstone: Elsevier; 2016. Pp.793-796.

[2] Sinnatamby CS, Last's anatomy. Regional and applied. 11 th Ed. Churchill Livingstone, Edinburgh, 2006. Pp 102-105.

[3] Barden CR. Skeleton. American Journal of Anatomy. 1905;4:265-73.

[4] Flower WH, Garson JG. The scapular index as a race character in man. J of Anat Physiol. 1879;14(1):13-17.

[5] Singhal G, Rathod H, Patel A, Modi P, Prajapati S, Parmar RK. A study of measurements and indices of human scapula at Jamnagar medical college. International Journal of Respiratory Medicine. 2013;2(1):65-68.

[6] Nithya V, Murali P, Sundarapandian S. Anatomical basics and variations of the scapula in south Indian population. International Journal of Anatomy and Research. 2020;8(2.2):7519-25.
[7] Krishnaiah M, Nagaraj S, Praveen Kumar M, Sherke AR. Study of scapular measurements and scapular indices of Andhrapradesh Region. Journal of Denta and Medical Sciences. 2014;13(06):117-20.

[8] Nazir M, Shah BA, Shahdad S, Aslam B, Amin R. Scapular measurements and indices, an observational study at GMC Srinagar, Kashmir. International Journal of Current Research. 2018;10(03):67125-28.

[9] von Schroeder HP, Kuiper SD, Botte MJ. Osseous anatomy of scapula. Journa of Clin Orthop Relat Res. 2001;(383):131-39.

[10] Comas JC. Manual of physical Anthropology. USA: Thomas Springfield, Illinois publishers; 1960. Pp 418-420.

[11] Krogman WM, Iscan MY. Determination of Sex and Parturition by scapula the human skeleton in forensic medicine, $2^{\text {nd }}$ edition, USA: Charles Thomas publishers; 1986. Pp 135-228.

[12] Inman VT, Saunders JB, Abbott LC. Observation on the function of the shoulder joint. Journal of Bone \& Joint Surgery. 1944;1:30

[13] Guise Sheridan S, Ullinger J, Ramp J, Humbert JB, Gunneweg J. Anthropologica analysis of the human remains: the French Collection. Fouilles de Khirbet Qumrân et'Ain Feshkha II. Études d'anthropologie, de physique et de chemie. Studies of anthropology, physics and chemistry. 2003:129-69.

\section{PARTICULARS OF CONTRIBUTORS:}

1. Professor and Head, Department of Anatomy, Father Muller Medical College, Mangalore, Karnataka, India.

2. Assistant Professor, Department of Anatomy, Father Muller Medical College, Mangalore, Karnataka, India.

3. Associate Professor, Department of Anatomy, Apollo Institute of Medical Sciences and Research, Chittoor, Andhra Pradesh, India.

NAME, ADDRESS, E-MAIL ID OF THE CORRESPONDING AUTHOR:

Dr. MS Somesh,

Professor and Head, Department of Anatomy, Father Muller Medical College, Father Muller Road, Kankanady, Mangalore-575002, Karnataka, India.

E-mail: drsomeshms@fathemuller.in

\section{AUTHOR DECLARATION:}

- Financial or Other Competing Interests: None

- Was Ethics Committee Approval obtained for this study? Yes

- Was informed consent obtained from the subjects involved in the study? NA

- For any images presented appropriate consent has been obtained from the subjects. NA
PLAGIARISM CHECKING METHODS: [Jain Het al.]

- Plagiarism X-checker: Feb 10, 2021

- Manual Googling: May 01, 2021

- iThenticate Software: May 13, 2021 (7\%)
ETYMOLOGY: Author Origin

Date of Submission: Feb 09, 2021

Date of Peer Review: Mar 25, 2021

Date of Acceptance: May 03, 2021

Date of Publishing: Jul 01, 2021 